\title{
KEPENTINGAN KEBIJAKAN PEMBUATAN PERATURAN DAERAH PROVINSI DAERAH KHUSUS IBUKOTA (DKI) JAKARTA NO. 4 TAHUN 2007 (PENGENDALIAN, PEMELIHARAAN DAN PEREDARAN UNGGAS) DAN IMPLIKASINYA TERHADAP USAHA PENDISTRIBUSIAN UNGGAS DI DKI JAKARTA
}

\author{
Siti Mariam \\ Institut Ilmu Sosial dan Manajemen STIAMI Jakarta \\ ws.marry@yahoo.co.id
}

\begin{abstract}
Abstrak. Penelitian ini dilakukan untuk: (1) mengetahui pertimbangan yuridis, filosofis, dan sosiologis dari peraturan pendistribusian unggas di Provinsi DKI Jakarta, (2) mengkaji dan menganalisa pengaturan relokasi dan pendistribusian unggas di Provinsi DKI Jakarta, (3) mengetahui dampak Peraturan Daerah Nomor 4 Tahun 2007 terhadap usaha perunggasan.

Penelitian ini dilakukan berdasarkan Peraturan Daerah Nomor 4 Tahun 2007, didukung dengan dokumen resmi yang berasal dari pihak yang berkompeten di bidang perunggasan. Penguatan data diperoleh melalui studi kepustakaan, literatur-literatur ilmiah, buku-buku, majalah/jurnal ilmiah, data statistik, karya ilmiah (makalah dan tesis), serta berasal dari hasil wawancara langsung di lapangan terhadap pelaku perunggasan. Data di analisis dengan metode kualitatif dan kuantitatif. Hal ini erat kaitannya dengan tipe penelitian yang bersifat deskriptif dan merupakan penelitian hukum normatif.

Berdasarkan hasil pembahasan diketahui bahwa kepentingan kebijakan pembuatan Peraturan Daerah Nomor 4 Tahun 2007 adalah untuk mencegah perkembangan dan penularan penyakit flu burung sehingga masyarakat keseluruhan terbebas dari flu burung dan memberikan kesempatan ekonomi kepada pemerintah daerah atau pihak swasta yang ditunjuk untuk mengelola tempat penampungan ayam (TPnA) dan tempat pemotongan ayam (TPA) guna memperoleh pendapatan pengelolaan. Dengan ditetapkannya tempat TPnA dan TPA di lima lokasi menyebabkan industri penampungan dan pemotongan ayam lebih terkonsentrasi dan intensitas persaingan usaha pada industri perunggasan menjadi berkurang. Penunjukan PT Kartika Eka Dharma di wilayah Jakarta Barat dan PT Dharma Jaya serta PD Dharma Jaya sebagai tempat pemotongan ayam dan operator pengelolaan tempat pemotongan ayam merupakan bentuk diskriminasi yang dilakukan pemerintah terhadap pelaku usaha perunggasan.
\end{abstract}

Kata Kunci: Kajian Peraturan Daerah.

Abstract. This research was conducted to find out the following matters: (1) the juridical, philosophy, and sociology aspects of DKI Jakarta Province regulation on poultry distribution, (2) observing and analyzing the poultry relocation and distribution in DKI Jakarta Province, (3) analyzing the implication of local regulation number 4 year 2007 in poultry business.

This research was conducted based on local regulation number 4 year 2007 which was supported by legal documents from competence resources in poultry business. The data collected was supported by library research, scientific literatures, books, scientific magazines/journals, statistic data, scientific articles, and reports, and interview to the poultry businessmen. The data was analyzed by using qualitative and quantitative methods due to the type of this research as descriptive study and was legal normative research study.

The discussion came to the finding that the importance of composing local regulation policy in DKI Jakarta Province number 4 year 2007 was to prevent the disseminating and the spreading of avian influenza in order to protect the community and to provide economic opportunity for local 
Jurnal Ilmiah Untuk Mewujudkan Masyarakat Madani ISSN 2355-309X

government or private sectors to manage the chicken accommodating location (TpnA) and the chicken butchering location (TPA) in order to get income. By deciding the TpnA and TPA in five location, it caused the accommodation and the butchering industries more concentrated and decrease the competition intensity in poultry business. PT Kartika Eka Dharma in west Jakarta and PT Dharma Jaya as well as PD Dharma Jaya that were appointed as chicken butchering location and chicken accommodating location operators became the form of government discrimination toward the poultry businessmen.

Key Word: Study of Local Regulation.

\section{PENDAHULUAN}

Merebaknya wabah Avian Influenza (AI) sejak 2003 membuat masyarakat perunggasan dari hulu sampai hilir (pengusaha, peternak kemitraan, peternak rakyat, pemasok ayam, penampung ayam, pemotong, dan pedagang ayam) semakin terhimpit. Saat ini flu burung telah menjadi endemik di 31 provinsi dan telah dinyatakan zoonosis. Kondisi ini patut dicermati, karena tidak hanya berdampak pada kematian ternak, tetapi secara ekonomi berpotensi menurunkan sumber pendapatan pelaku usaha ternak unggas dan mengurangi permintaan konsumen terhadap produk unggas. Lebih penting lagi, implikasi yang akan timbul cukup besar, mengingat sebagian besar penduduk Indonesia hidup berdekatan secara sosio kultural dengan unggas.

Flu burung merupakan fenomena yang cukup unik. Seiring dengan pemberitaan korban flu burung di berbagai media massa, banyak pihak yang khawatir akan penyakit ini. Namun ketika flu burung mulai mereda dan sepi pemberitaan, masyarakat mulai lupa akan penyakit tersebut. Rancunya pemberitaan mengenai flu burung salah satunya dikaitkan dengan korban penyakit ini yang diduga (suspect) flu burung. Namun baik pada saat ramai atau sepi pemberitaan flu burung, pelaku usaha unggas tidak terpengaruh. Mereka beranggapan bahwa belum ada bukti korban flu burung pada pelaku usaha ternak unggas, kendati demikian penyakit flu burung tetap harus diwaspadai.

Aspek kesehatan dan jumlah penduduk DKI Jakarta yang lebih dari 7 juta jiwa melatarbelakangi keluarnya Peraturan Daerah (Perda) DKI No. 4 Tahun 2007, yang diawali dengan keluarnya Peraturan Gubernur No 15
Tahun 2007. Kebijakan ini merevisi Perda No. 5 Tahun 1992 tentang penampungan dan pemotongan unggas serta peredaran daging unggas di wilayah DKI Jakarta (lembaran DKI Jakarta tahun 1992 No. 75). Jenis unggas yang termasuk dalam peraturan adalah ayam, itik, entog, angsa, merpati dan puyuh. Kasus di DKI Jakarta menunjukkan sepanjang 20062007, flu burung telah memakan tiga korban jiwa manusia. Wilayah yang termasuk dalam kategori terdeteksi flu burung meliputi tiga kecamatan di Jakarta Pusat, dua kecamatan di Jakarta Utara, tujuh kecamatan masingmasing di Jakarta Timur dan Selatan, dan tiga kecamatan di Jakarta Barat.

Sebagai Ibukota Negara, DKI Jakarta diberi predikat sebagai daerah khusus (special territory). Sebagai konsekuensi dari status dan predikat ini, DKI Jakarta telah diberi otonomi khusus dalam bentuk otonomi tunggal (single autonomy) yang implementasinya ada pada tingkat provinsi. Dalam praktik penyelenggaraan Pemda DKI Jakarta sering dijumpai kenyataan belum semaksimal mungkin melibatkan masyarakat banyak dalam pembentukan, terhadap implementasi-nya seluruh warga masyarakat diwajibkan untuk ikut terlibat dan mendukung penuh serta menyukseskannya. Dalam hal ini, kebijakan Perda No. 4 Tahun 2007 harus dimengerti dan dipahami oleh seluruh pelaku usaha perunggasan sampai sejauh mana dapat mematuhi Perda ini. Perumusan masalah yang dibuat adalah:

1. Pertimbangan apa saja yang melatarbelakangi pengaturan/legislasi pendistribusian unggas di Provinsi DKI Jakarta? 
Siti Mariam, Kepentingan Kebijakan Pembuatan Peraturan Daerah Provinsi Daerah Khusus...

2. Bagaimana pengaturan relokasi dan pendistribusian unggas di Provinsi DKI Jakarta?

3. Apa dampak Peraturan Daerah No. 4 Tahun 2007 terhadap usaha perunggasan?

\section{TINJAUAN PUSTAKA}

Konsep dasar yang dapat digunakan dalam ekonomi politik dipakai sebagai sinonim atau nama lain istilah dari ilmu ekonomi (Lane \& Erson: 1994: XI). Pada perkembangannya, studi ekonomi politik dinyatakan sebagai salah satu analisis ekonomi atas suatu negara-bangsa (nationstate). Apabila mengutip pengertiannya yang bersumber dari kamus induk ilmu ekonomi, ekonomi politik digambarkan sebagai bentuk keterikatan antara fakta-fakta produksi, keuangan dan perdagangan dengan kebijakan pemerintah di bidang moneter, fiskal dan komersial. Meskipun disebutkan pula bahwa ekonomi politik merupakan istilah lama dari ilmu ekonomi (A New Dictionary of Economics and: 1996).

Meskipun banyak kekaburan makna dan kelemahan dalam kerangka berpijak, namun pembahasan dengan menggunakan pendekatan analisis ekonomi politik masih banyak dilakukan oleh sebagian pakar ekonomi. Tujuannya adalah untuk menformalkan kajian-kajian yang menaruh kepada perhatian (concert) tertentu, terutama terhadap kebijakan-kebijakan ekonomi publik (economy of public policy), dengan focusfokus pertanyaan politis mengenai siapa yang diuntungkan, siapa yang dirugikan dari adanya kebijakan dan bagaimana prosesnya (Haryadi, 1991: 14). Bahkan ilmu ekonomi politik bisa dijadikan sebagi "jembatan" untuk memahami realitas dan proses ekonomi yang berkaitan dengan proses politik, sehingga merupakan "sinergi" antara keduanya.

Terkait reformasi ekonomi, pada dasarnya dilakukan untuk merubah secara fundamental dan permanen cara kegiatankegiatan ekonomi diorganisasikan, dikoordinasikan dan diregulisasikan. Reformasi ekonomi dikatakan sukses dan bekerja dengan baik jika terjadi pergeseran factor-faktor produksi dari sector yang kurang produktif menjadi sektor yang produktif. Tujuan reformasi adalah memperbaiki cara perekonomian yang bekerja lebih efisien, sehingga makin banyak masyarakat yang mengalami perbaikan kesejahteraan ekonominya (Ikhsan: 2000: 46). Dengan demikian kesuksesan reformasi ekonomi sangat tergantung kepada enterpreneur untuk memindahkan tenaga kerja dan modal sebagai tanggapan terhadap reformasi ekonomi. Dalam menjalankan proses ini biaya penyesuaian tergolong signifikan dan tergantung pada karakteristik industri. Keinginan enterpreneur dan pekerja untuk menanggung biaya secara natural sangat tergantung pada pandangan mereka tentang kelanjutan proses reformasi itu sendiri.

Konsep dasar kebijakan di bidang ekonomi ini dituangkan dalam berbagai macam peraturan, sehingga suatu kajian kebijakan yang pada hakekatnya merupakan suatu kajian terhadap suatu peraturan perundang-undangan (17 (Mustopadidjaja, 1992: 30). Kebijakan di sini merupakan tindakan politik atau juga rangkaian instruksi dari pembuat kebijakan yang ditujukan kepada pelaksana. Menurut Weimer dan Vining, apabila berbicara mengenai kebijakan, maka tidak akan lepas dengan pihak individu maupun lembaga yang melakukan analisis kebijakan. Weimer dan Vining mendefinisikan analisis kebijakan (policy analysis) sebagai suatu objek yang berorientasi kepada suatu pertimbangan keputusan publik dengan menggunakan nilainilai social (Weimer \& Vining, 1992: 1). Hal ini bias melalui proses pembuatan yang pertama pengumpulan agenda permasalahan, kedua perumusan kebijakan (policy formulations), ketiga pengambilan berbagai alternative kebijakan ( policy adoption), keempat pelaksanaan kebijakan (implementation policy), dan terakhir yang harus dilalui adalah fase penelitian kebijakan (assesment policy). Sehingga dalam pengumpulan agenda permasalahan para pembuat kebijakan berusaha untuk mengumpulkan dan menentukan permasalahan utama dari agenda publik yang terjadi. Fase ini merupakan fase dimana seorang pembuat kebijakan memilih permasalahan mana yang harus segera diselesaikan dan permasalahan mana yang bisa ditunda. 
Ada yang perlu diperhatikan dalam proses pembuatan kebijakan sebagai produk dari proses sistem politik memberikan suatu gambaran mengenai penataan pada setiap tingkatan (levels) dalam proses pembuatan kebajikan. Ada tiga level kebajikan dalam hierarki proses pembuatan kebajikan. Pertama, level kebajikan yaitu pernyataan atau statemen mengenai tujuan nasional dibahas dan diformulasikan. Kemudian level organisasi dimana kebijakan dibuat oleh lembaga eksekutif sesuai dengan visi dan misi yang ditentukan pada level kebijakan. Terakhir level operasional dimana peraturan teknis dijabarkan untuk dilaksanakan oleh unit operasional. Hasilnya disaksikan langsung oleh pelaksana dan masyarakat. Kebijakan ini pula yang bias dilakukan pada hal pengunggasan.

Avian Influenza (AI) disebut juga flu burung, fowl pest, fowl plaque atau avian flu dapat terjadi dalam 2 bentuk, yakni Highly Pathogenic Avian Influenza (HPAI) atau fowl plaque atau Low Pathogenic Avian Influenza (LPAI) yang keduanya disebabkan oleh virus Influenza tipe A. Virus ini termasuk family Orthomyxovirydae, yang berukuran $80-120$ $\mathrm{nm}$, dan berdasarkan karakter protein $M$ nya dibedakan menjadi 3 tipe A, B dan C. Tipe B dan $\mathrm{C}$ hanyaditemukan pada manusia dan kasusnya bersifat ringan. Sedag tipe A yang utama adalah menyerang unggas, walaupun juga ditemukan pada manusia, kuda, babi, dan terkadang pada spesies mamalia lainnya. Berdasarkan "spike" haemaglutinin (HA) dan neurainidase (NA) pada amplop (pembungkus luar virus) maka virus infuenza ditentukan subtipenya. Virus Influenza A memiliki 15 HA (H1-H15) dan 9 NA (N1-N9) yang berbeda secara antigenic. Hingga saat ini, semua wabah penyakit HPAI yang sangat patogen pasti disebabkan subtipe $\mathrm{H} 5$ atau $\mathrm{H} 7$, namun tidak sebaliknya (Swayne dan Suarez, 2000).

Hampir semua unggas peka terhadap virus infuenza, baik unggas yang sudah didomestikasi misalnya ayam, kalkun, burung puyuh, itik, angsa,bebek, maupun unggas yang masih liar seperti burung kakatua.
Penyakit dapat ditularkan melalui kontak langsung dengan sumber penularan, yakni sekresi hidung, mata dan feses dari unggas terinfeksi yang masuk melalui mulut, mata, hidung. Feses yang terkontaminasi virus AI dapat tahan sampai waktu yang sangat lama terutama dalam keadaan sejuk dan lembab (Cidrap, 2004). Di Indonesia, virus LPAI sudah diisolasikan dari itik, burung pelikan dan bebek pada 1983 dan diidentifikasi sebagai H4N6 dan H4N2.3 Sejak saat itu, tidak ada lagi laporan mengenai kejadian penyakit baik LPAI maupun HPAI hingga kemudian pada petengahan September 2003, Balai Penelitian Veteriner (Balitvet) bersama dengan Balai Penyidikan dan Pengujian Veteriner (BPPV) Wilayah IV Wates diminta oleh Direktorat Kesehatan menangani wabah penyakit unggas yang pada waktu itu sedang terjadi di Jawa Timur. Berdasarkan laporan resmi Direktorat Kesehatan Hewan wabah ini diduga sudah terjadi sejak Agustus 2003 di Jawa Tengah.

Namun kejadian sebenarnya sangat sulit untuk ditelusuri kembali. Pada saat Balitvet diminta menangani wabah penyakit ini, pada September 2003, penyakit ini telah menyebar dari Jawa Tengah ke Jawa Timur dan diduga juga ke Jawa Barat. Wabah ini tidak hanya menyerang ayam petelur komersial, namun juga ayam pedaging, burung puyuh, dan burung unta serta ayam jengger dan pial, leleran hidung dan hipersalivasi, ptechiae subkutan pada kaki dan paha, diare dan kematian tinggi yang mendadak (Damayanti et al, 2004). Melihat perkembangan penyakit, maka dikhawatirkan penyakit ini dapat segera menyebar ke pusat-pusat unggas di Indonesia sehingga mengakibatkan kerugian ekonomi yang sangat besar.

Analisis kebijakan publik semestinya menjadi suatu kepemimpinan atau kemahiran sebagai cara bertindak pemerintah. Secara umum kebijakan publik yang dirumuskan oleh pemerintah, baik secara intitusional maupun perorangan menjadi suatu daftar pilihan tindakan yang saling berhubungan, yang disusun oleh intitusi atau pejabat pemerintah. Atau dengan kata lain kebijakan 
Siti Mariam, Kepentingan Kebijakan Pembuatan Peraturan Daerah Provinsi Daerah Khusus...

adalah proses sosial dimana proses intelektual melekat didalamnya tidak berarti bahwa efektivitas relatif dari proses intelektual tidak dapat ditingkatkan, atau bahwa proses sosial dapat "diperbaiki". Didasarkan pada pengertian di atas, dapat digunakan definisi analisis kebijakan publik yang diadopsi dari Thomas Dye, yaitu analisis untuk mengetahui apa yang dikerjakan oleh pemerintah, mengapa mereka mengerjakan hal tersebut, dan keberhasilan apa yang hendak dicapai dengan pekerjaan tersebut.

\section{METODE PENELITIAN}

Metode penelitian yang digunakan dalam penulisan ini adalah metode deskriptif analisis yang meliputi analisis teoritis dan empiris dengan teknik pengumpulan data berupa studi kepustakaan dan studi lapangan kepada pihakpihak terkait yang relevan dengan masalah yang dibahas, serta melakukan wawancara dengan pejabat terkait dan pengisian daftar pertanyaan oleh para pelaku perunggasan. Metode penelitian deskriptif merupakan prosedur pemecahan masalah yang dilakukan dengan cara menggambarkan/melukiskan keadaan subyek/objek penelitian (seseorang, lembaga, masyarakat dan lain-lain) pada saat sekarang berdasarkan fakta-fakta yang tampak atau sebagaimana adanya (Prasetya Irawan, 1999:60). Dalam penelitian deskriptif, data yang dikumpulkan berupa kata-kata, gambar dan angka-angka. Hal ini berkaitan dengan penerapan metode kualitatif dalam pengumpulan data (data kualitatif). Adapun sifat penelitian mengenai kepentingan kebijakan pembuatan peraturan daerah Provinsi Daerah Khusus Ibukota Jakarta No. 4 Tahun 2007 dan implikasinya terhadap pendistribusian unggas di DKI Jakarta memakai metode yuridis normative yang bersifat kualitatif dan kuantitatif. Penelitian yuridis normatif merupakan penelitian yang mengacu kepada norma-norma hukum.

Lokasi penelitian yang dilakukan dalam pengumpulan data, penulis banyak mengunjungi pelaku perunggasan yang ada di DKI Jakarta untuk mengumpulkan data primer dari para nara sumber dan responden. Selain itu penulis banyak mengumpulkan data dengan mengunjungi perpustakaan dan institusi yang berkopenten dalam kebijakan perunggasan yaitu Dinas Peternakan dan Kelautan, Unit Pengendali Penyakit Avian Influenza Pusat (UPP-AI Pusat), Departemen Pertanian, Komisi Nasional Pengendalian Flu Burung dan Kesiapsiagaan Menghadapi Pandemi Influenza (Komnas FBPI) dan Balitvet (Badan Balai Veteriner) dan Komisi B DPRD DKI Jakarta. Pengambilan data juga dilakukan dengan melakukan kajian yang bersumber dari organisasi yang secara intens telah melakukan berbagai kajian di bidang perunggasan, yaitu FMPI (Forum Masyarakat Perunggasan Indonesia) yang terdiri dari GAPPI, GPMT dan HPUJ.

Metode pengumpulan data berlandaskan pada sifat dari penelitian deskriptif, untuk memperoleh data yang dibutuhkan makan metode pengumpulan data dilakukan dengan cara:

1. Wawancara dilakukan untuk memperoleh data/informasi dari subyek atau responden (dalam hal ini informan) yang terkait dengan masalah yang diteliti. Untuk maksud tersebut, maka informan dipilih secara sengaja (purposive), yakni informan yang memiliki kompetensi pengetahuan di bidang pendistribusian unggas. Wawancara dilakukan dengan menggunakan interview guide (pedoman wawancara) dengan daftar pertanyaan disesuaikan dengan karakteristik informan masing-masing. Wawancara berlangsung secara informal dan bersifat terbuka (wawancara terbuka) dengan maksud agar pembicaraaan berlangsung secara bebas tanpa terpaku pada urutan daftar pertanyaan.

2. Dokumentasi atau metode studi kepustakaan dilakukan dengan cara menelusuri literatur-literatur ilmiah, baik dari buku-buku dan majalah/jurnal ilmiah, data statistik, dokumen resmi, karya-karya ilmiah (makalah tesis). Sumber data dari dokumentasi merupakan sumber data kedua (data sekunder).

Untuk jenis data diperoleh dari berbagai informan terpilih secara selektif dari policy makers atau policy stake holders atau berbagai pihak yang berkopenten dan mewakili departemen terkait terutama institusi atau lembaga yang mempunyai 
kekuatan dalam mengambil kebijakan di sektor perunggasan. Jenis data hasil penelitian yang akan digunakan dalam penelitian ini adalah:

1. Data sekunder yang diambil dari institusi yang berkopenten di bidang perunggasan yaitu data yang bersumber dari Dinas Peternakan dan Kelautan, Unit Pengendali Penyakit Avian Influenza Pusat (UPP-AI Pusat) dan data dari Komite Nasional Pengendalian Flu Burung dan Kesiapsiagaan menghadapi Pandemi Influenza (Komnas FBPI). Data tertier, artinya data sudah diolah yang diambil dari organisasi yang secara intens telah melakukan berbagai kajian di bidang perunggasan. Metode dokumentasi (studi kepustakaan) dilakukan dengan cara menelusuri literatur-literatur ilmiah, baik dari bukubuku dan majalah/jurnal ilmiah, data statistik, dokumen resmi, karya-karya ilmiah (makalah, tesis). Sumber data dari dokumentasi merupakan sumber data kedua (sekunder).

2. Data Primer berupa hasil wawancara artinya pengambilan data sampel langsung kepada pihak ahli (experts) di lapangan yaitu para penampung unggas, pemotong unggas, pedagang unggas potong dan pemasok unggas di DKI Jakarta.

Kemudian data yang diperoleh dari penelitian ini di analisis dengan metode kualitatif dan kuantitatif. Hal ini erat kaitannya dengan tipe penelitian yang bersifat deskriptif dan merupakan penelitian hukum normatif. Dari hasil analisis diharapkan diperoleh gambaran dan pemahaman tentang kebijakan pembentukan Perda DKI Jakarta No. 4 Tahun 2007 dan implikasinya terhadap pendistribusian unggas di DKI Jakarta.

\section{HASIL PENELITIAN DAN PEMBAHASAN}

Saat ini di Provinsi DKI Jakarta terdapat 1.153 tempat pemotong ayam dan 219 tempat penampungan ayam yang tersebar di 5 wilayah dengan pasokan ayam unggas yang masuk ke DKI 700.000 ekor/hari dan kapasitas tampung 452.460 ekor/hari. Adapun pendistribusian ayam berdasarkan permintaan konsumen adalah $80 \%$ berupa ayam hidup, dan $20 \%$ atau sebanyak 200 ton/hari berupa ayam beku (umumnya untuk swalayan dan restoran). Daerah di Provinsi DKI Jakarta yang menjadi sentra TPA dan TpnA terdapat di sekitar Pulo Gadung, Matraman, Cakung, Jatinegara (Jakarta Timur), Cempaka Putih (Jakarta Pusat), dan Kemayoran (Jakarta Pusat). Selain daerah-daerah tersebut, TPA dan TpnA juga tersebar di Pasar Rebo, Kramat Jati (Jakarta Timur), Kalideres, Cengkareng, Grogol, Petamburan, Palmerah (Jakarta Barat), Tanang Abang, Menteng, Gambir, Senen (Jakarta Pusat), Pesanggrahan, Kebayoran Lama, Pasar Minggu, Pancoran, Tebet (Jakarta Selatan), dan Pademangan, Tanjung Priok, Kelapa Gading, Cilincing (Jakarta Utara).

Usaha TPA dan TpnA merupakan suatu usaha yang saling berkaitan dan saling membutuhkan. Jarak antara TPA dengan pasar dan TPA dengan TpnA sangatlah berpengaruh terhadap kelancaran usaha yang dijalankan. Jarak TPA dengan pasar kurang dari $1 \mathrm{~km}$ dirasa masih dalam keadaan wajar. Namun jika jaraknya sudah lebih dari $1 \mathrm{~km}$ merupakan jarak yang kurang kondusif bagi pemotong maupun karkas itu sendiri. Selain harus mengalokasikan sebagian dana untuk transportasi, kemungkinan tingkat kesegaran karkas yang dipasarkan akan berkurang. Tak berbeda dengan TPA, para pengusaha yang membangun TpnA kebanyakan adalah pemain lama. Menurut data survey didapatkan sebanyak $38 \%$ memulai usahanya pada 2000 an, 34\% memulai usaha pada 1980-an, sisanya memulai usaha sebelum 1980-an dan setelah 2009. Dari data tersebut dapat disimpulkan bahwa kebanyakan pengusaha TPA dan TpnA merupakan orang lama yang telah menekuni bisnis tersebut dengan baik.

Dalam praktik penyelenggaraan kebijakan Pemda DKI Jakarta sering dijumpai kenyataan belum semaksimal mungkin melibatkan masyarakat banyak dalam pembentukannya, namun terhadap 
Siti Mariam, Kepentingan Kebijakan Pembuatan Peraturan Daerah Provinsi Daerah Khusus...

implementasi-nya seluruh warga masyarakat diwajibkan untuk ikut terlibat dan mendukung penuh serta menyukseskannya. Perda No. 4 Tahn 2007 tentang Pengendalian Pemeliharaan dan Peredaran Unggas di DKI Jakarta setiap pembentukan dan pemberlakuan peraturan perundang-undangan hendaklah mengacu pada tiga pilar bangunan hukum yang harus menjadi pertimbangan pokok. Ketiga pertimbangan itu antara lain 1) pertimbangan yuridis, 2) pertimbangan filosofis, dan 3) pertimbangan sosiologis.

Pertama pertimbangan yuridis yang menjadi sumber pengesah dan sumber pengefektif peraturan perundang-undangan. Adanya peraturan perundang-undangan yang lebih tinggi yang menjadi dasar perintah dan tujukan pembentukannya. Aspek ini sudah pasti dapat dipenuhi dan diwujudkan bahkan dalam praktiknya cenderung berlebihlebihan. Sementara dari aspek perumusan normanya harus menjamin adanya kepastian hukum yaitu kejelasan tujuan yang harus diwujudkan (tujuan manifest) dan kejelasan upaya untuk mewujudkan tujuannya. Dalam konteks Perda DKI Jakarta No. 4 Tahun 2007, kepastian hukum dengan sangat jelas telah dirumuskan, yaitu pencegahan perkembangan penyakit flu burung, dan pemutusan mata rantai penyebaran flu burung.

Untuk mewujudkan kedua tujuan tersebut, Perda sudah merumuskan upayaupaya yaitu seperti tertuang dalam pasal 2 dan 3 yang harus dipenuhi oleh setiap orang (perseorangan atau badan hukum). Untuk mendapatkan izin pemeliharaan unggas pemohon harus melampirkan persyaratan. Sedangkan isi dari pasal 7, apabila dicermati terdapat politik kriminalisasi terhadap usaha pemeliharaan, penampungan dan pemotongan, serta peredaran unggas yang tidak memenuhi persyaratan yang ditentukan dalam Perda. Namun dalam Perda DKI No 4 Tahun 2007 ini terdapat aspek yang mengganggu jaminan kepastian hukum, yaitu:

1. Ketentuan persyaratan perolehan izin pemeliharaan unggas dan kriteria lokasi tempat penampungan yang mengandung kelemahan internal yaitu: pertama ada ketidak-konsistenan antara ketentuan subyek (perseorangan dan badan hukum) yang diberi peluang untuk melakukan usaha pemeliharaan sebagaimana dirumuskan dalam Pasal 2 ayat (1), sedangkan syarat bagi badan hokum belum ditegaskan; kedua, substansi persyaratan sebagaimana dirumuskan dalam Pasal 2 ayat (4) hanya bersifat administratif.

2. Perda sebagaimana dapat dibaca dalam Pasal 6 tidak menentukan mengenai kriteria lokasi tempat penampungan dan pemotongan unggas, namun menyerahkan kepada gubernur untuk menentukan dan mengatur lebih lanjut. Hal ini mengandung makna bahwa DPRD tidak berusaha untuk memberikan batasan kriteria yang harus diikuti oleh gubernur dan sebaliknya menyerahkan sepenuhnya kepada Gubernur untuk mengisi dan menetapkan kriteria lokasi sesuai dengan keinginan dan kepentingan Pemda DKI.

3. Perda ini sejak semula didisain dan dibentuk untuk melakukan penggusuran terhadap pelaku usaha kecil di sektor penampungan dan pemotongan unggas. Hal ini dengan tegas ditentukan dalam Pasal 6 yang menentukan perintah untuk pindah ketempat yang ditetapkan Pemda. Artinya, Perda ini tidak memberikan hak kepada pengusaha kecil untuk memberikan masukan kecuali harus tunduk kepada keputusan Gurbernur. Hal ini merupakan wujud dari otoritarian dalam pembentukan peraturan perundang-undangan. Politik otoritarian ini semakin nyata kerena perda seperti tertuang dalam Pasal 7 tidak mewajibkan Pemda untuk melakukan pembinaan kepada pengusaha kecil panampungan dan pemotongan hewan.

Selanjutnya ada pertimbangan filosofis terkait dengan nilai-nilai yang menjadi landasan dari norma-norma yang terdapat dalam peraturan perundang-undangan. Hanya saja pertimbangan filosofis ini tidak dipahami dan digunakan secara utuh kecuali yang sangat parsial-pragmatis seperti yang tertuang dalam "Bagian Menimbang" termasuk dalam Perda No. 4 tahun 2007, yang kemudian dijabarkan lebih rinci kedalam norma. 
Padahal pertimbangan filosofis ini berkaitan dengan minimal dua nilai, yaitu:

a. Nilai keadilan yang pada umumnya harus diacu yaitu:

(1) Komutatif, yang memberian perhatian atas kepentingan bersama seluruh masyarakat. Dalam konteks Perda No. 4/2007, keadilan komutatif ini sudah dituangkan yaitu kepentingan untuk mencegah perkembangan dan penularan penyakit flu burung sehingga masyarakat secara keseluruhan terbebas dari penyakit yang merisaukan tersebut;

(2) Keadilan distributif yang memberikan perhatian atas kepentingan pihak yang berkontribusi atau berjasa pada kepentingan bersama. Dalam konteks Perda No 4 Tahun 2007, keadilan distributif secara implisit terwujud dalam pemberian kesempatan kepada unsur Pemda atau swasta untuk mengelola tempat penampungan dan pemotongan di lokasi yang baru;

(3) Keadilan korektif yang memberikan perhatian atas kepentingan kelompok masyarakat yang lemah secara sosial ekonomi yang akan menerima dampak negatif dari pemberlakuan peraturan perundangundangan. Dalam konteks Perda No 4 Tahun 2007, keadilan korektif belum tampak dijabarkan. Ketentuan Pasal 7 yang mewajibkan kepada pelaku usaha kecil penampungan dan pemotongan untuk pindah dari lokasi lama ke lokasi baru menunjukkan penundukkan kepentingan kelompok ini terhadap kemauan pemerintah dan/atau mungkin kepentingan swasta yang berada di balik pembangunan tempat baru.

Ketiga nilai keadilan di atas harus diakomodasi secara keseluruhan, jika peraturan perundang-undangan yang terbentuk dikehendaki menjadi instrument yang efektif yaitu mewujudkan tujuan utamanya dan mencegah dampak sampingan yang negative seperti diuraikan di atas.

b. Nilai ideologi berkaitan dengan paradigma yang menjadi landasan dari setiap pembentukan peraturan perundang-undangan yang berfungsi sebagai alat rekayasa mewujudkan kondisi sosial-ekonomi-politik tertentu. Ada 2 (dua) ideologi yang mendasari namun saling bertentangan sehingga harus dilakukan pilihan, yaitu:

(1) Ideologi otoritarianisme yang menekankan adanya pemaksaan dan penundukkan kemauan semua kelompok masyarakat terhadap keinginan atau kepentingan Pemerintah/Pemda. Dibelakang kepentingan pemerintah ini bukan tidak mungkin tersembunyi kepentingan kelompok lain seperti misalnya pelaku usaha besar swasta;

(2) Ideologi egalitirisme yang menekankan pada upaya untuk memberikan perlindungan dan pengayoman terhadap kepentingan kelompok masyarakat yang lemah dengan tetap mewujudkan tujuan manifest dari peraturan perundangundangan. Selama ini politik perundang-undangan kita masih diwarnai oleh ideology otoritarianisme, termasuk yang terjadi dalam Perda No. 4 Tahun 2007. Pemaksaan masih menjadi bingkai besarnya, sedangkan pada pengayoman pada kepentingan kelompok yang lemah masih cenderung terabaikan. Padahal, perkembangan yang ada sekarang di Indonesia sudah didorong melalui kontrol publik dan keberanian masyarakat mengawasi ke arah ideologi egalitirisme. Karenanya DPRD harus memberikan perhatian terhadap ini agar produk hukumnya tidak menimbulkan permasalahan 
Siti Mariam, Kepentingan Kebijakan Pembuatan Peraturan Daerah Provinsi Daerah Khusus...

baru namun justru meniadakan dampak sampingan yang negatif.

Kemudian pertimbangan sosiologis terkait dengan pemberian perhatian terhadap realitas masyarakat Indonesia yang majemuk kondisi sosial ekonominya. Ada kelompok masyarakat yang kuat secara sosial ekonomi dan politik dengan kekayaan atau kekuatan modal yang besar dan hubugan yang baik dengan penguasa negara. Ada kelompok yang menengah dengan kekayaan atau kekuatan modal yang relative besar dan hubungan yang relatif baik dengan penguasa negara. Ada juga kelompok yang lemah secara sosial ekonomi dan politik dengan kekayaan kekuatan modal terbatas pas pasan sekedar bertahan hidup dengan akses komunikasi ke penguasa negara relatif tertutup kecuali ketika terjadi "pemilihan umum" atau pemilihan legislatif atau pemilihan presiden atau kepala daerah.

Mencermati Perda No.4 Tahun 2007, tampaknya masih belum mampu melepaskan diri dari pola lama yaitu ketidak-berpihakan kepada kelompok masyarakat yang lemah yang oleh UUD 1945 seharusnya mendapat perlindungan dan pengayoman termasuk fasilitas dan kemudahan. Bahkan sebaliknya Perda ini secara implisit membuka kemungkinan adanya "perkawinan siri" antara Pemda dengan kelompok masyarakat yang kuat secara sosial ekonomi dan politik. Di sinilah sebenarnya peranan DPRD sebagai wakil rakyat harus tampil ke depan untuk membentuk Perda yang mengayomi kelompok yang telah dan mencegah perkawinan siri antara penguasa dengan yang kuat.

Pengaturan relokasi pendistribusian unggas di Provinsi DKI Jakarta dapat dilihat dari:

1. Kebijakan Relokasi Penampungan dan Pemotongan Unggas.

Dimana relokasi tidak menyelesaikan masalah, hanya memindahkan masalah. Lepas tangannya Pemda DKI melalui Dinas Kelautan dan Pertanian, serta gagalnya kinerja dari Dinas Peternakan terjawab bila Perda No 4 Tahun 2007 dilaksanakan. Perda ini menjawab kinerja Dinas Peternakan yang bekerja seperti pemadam kebakaran dalam pengendalian flu burung. Bukan akar permasalahan yang diselesaikan. Flu burung ada pada unggas dan tidak perlu menjadi momok yang menakutkan. Upaya pencegahan flu burung di Provinsi DKI Jakarta sudah dengan (1) Peraturan Daerah Provinsi DKI Jakarta Nomor 4 Tahun 2007 tentang Pengendalian Pemeliharaan dan Peredaran Unggas; (2) Peraturan Gubernur Provinsi DKI Jakarta No. 146 Tahun 2007 tentang Petunjuk Pelaksanaan Peraturan Daerah No. 4 Tahun 2007; (3) Peraturan Gubernur Provinsi DKI Jakarta No. 147 Tahun 2007 tentang Komite Provinsi Pengendalian Flu Burung (Avian Influenza) dan Kesiapsiagaan menghadapi pandemi Influenza; dan (4) Instruksi Gubernur Provinsi DKI Jakarta Nomor 25 Tahun 2008 tentang Peningkatan Pelaksanaan Pengendalian Pemeliharaan dan Peredaran.

Wawancara dengan Bapak Afif, pedagang ayam dari Pasar Meser Jakarta Timur adalah sebagai berikut: "Saya menggeluti usaha ini sudah lebih dari 30 tahun hidup dengan darah, kotoran dan saliva ayam. Cukup dengan hidup sehat dan bersih maka kita dapat terhindar dari sakit, bukan hanya dari virus flu burung. Dengan cahaya matahari, air sabun bekas cucian, ataupun bayclin tanpa desinfektan maka virus flu burung akan mati. Dengan pemasakan 60 derajat maka produksi unggas bebas virus flu burung sudah dapat dikonsumsi. Pemberitaan flu burung yang tidak seimbang di media massa dan eletronik, merupakan penyebab unggas menjadi momok yang menakutkan dan patut dihindari. Ini menunjukkan lemahnya kinerja Departemen Pertanian dan Dinas Peternakan selama ini”.

Di DKI Jakarta tidak ada peternakan, pasal ini lebih cocok ditujukan kepada Poultry/Peternakan yang berada di luar wilayah DKI Jakarta. Di DKI Jakarta hanya ada penampung, pemotong, dan pengecer unggas yang mana dalam 1 - 2 hari unggas pangan yang didistribusikan habis. Pasal ini membatasi usaha perekonomian pelaku perunggasan yang selama ini sudah eksis 
memberdayakan sumber daya manusia di DKI Jakarta dan menambah pemasukan pajak untuk DKI Jakarta. Sebagai pelaksanaan Peraturan Daerah Nomor 4 Tahun 2007, Pemerintah Daerah DKI Jakarta kemudian menetapkan lima Tempat Penampungan (TpnA) dan Tempat Pemotongan Ayam (TPA) berdasarkan Keputusan Gubernur Nomor 1909 Tahun 2009 tentang Perubahan Lokasi Atas Keputusan Gubernur Nomor 1627/2009 tentang Lokasi Penampungan dan Pemotongan Ayam. Keputusan tersebut berisi penetapan tempat-tempat tertentu yang dijadikan penampungan dan pemotongan ayam sebelum didistribusikan di wilayah Provinsi DKI Jakarta.

Keputusan Gubernur tersebut menetapkan hanya lima tempat yang dijadikan pusat penampungan dan pemotongan ayam di Jakarta, sebagai berikut:

a. Rumah Pemotongan unggas Rawa Kepiting dengan luas $2 \mathrm{Ha}$ berlokasi di Jalan Rawa Kepiting, Kawasan Industri Pulo Gadung, Kelurahan Jatinegara RT 09 RW 10, Kecamatan Cakung, Kota Administrasi Jakarta Timur;

b. Rumah Pemotongan Unggas Cakung dengan luas $1 \mathrm{Ha}$ berlokasi di Jalan Raya Penggilingan, Kecamatan Cakung, Kota administrasi Jakarta Timur;

c. Rumah Pemotongan Unggas Pulogadung dengan luas $8.000 \mathrm{~m} 2$ berlokasi di Jalan Palad No.2 (Kawasan RPH Pulogadung), Kelurahan Pulogadung, Kecamatan Pulogadung, Kota Administrasi Jakarta Timur;

d. Rumah pemotongan Unggas Petukangan Utara dengan luas 9.616 m2 berlokasi di Jalan Mochtar (Kawasan Kebun Bibit Petukangan Utara), Kelurahan Petukangan Utara, Kecamatan
tegasPesanggrahan, Kota

Administrasi Jakarta Selatan; dan e. Rumah Pemotongan Unggas PT. Kartika Eka Dharma dengan luas $12.483 \mathrm{~m} 2$ berlokasi di Jalan Swadarma Raya No. 69, Kelurahan Srengseng, Kecamatan Kembangan, Kota Administrasi Jakarta Barat.

Pemenuhan konsumsi produk unggas DKI setiap harinya dipasok dari Jawa Barat (Bogor, Subang, Sukabumi, Garut, dan Tasikmalaya), Jawa Tengah, Banten, dan Lampung. Tak kurang 400.000 ekor ayam hidup melintasi jalanjalan akses menuju maupun dalam kota Jakarta setiap harinya. Pemotongan sebagian besar dilakukan di TPA yang totalnya mencapai 1153 titik, tersebar di 5 kotamadya, Jakarta Pusat, Jakarta Timur, Jakarta Selatan, Jakarta Barat,dan Jakarta Utara. Sekian banyak TPA memliki kapasitas potong kurang lebih 452.460 ekor/hari. Sebelum dipotong, ayam-ayam ini terkumpul dipangkalan ayam tersebar di 219 lokasi. Kecuali ayam hidup, sekitar 30\% kebutuhan daging unggas Jakarta juga disuplai dalam bentuk karkas. Setiap harinya sekitar 200 ton karkas ayam masuk ke Jakarta.

Hasil pengamatan penulis ke lima lokasi yang ditunjuk berdasarkan SK Gubernur DKI Jakarta, ternyata yang paling siap berupa bangunannya adalah TPnA/TPA Rawa Kepiting. Telah diuraikan di atas bagaimana kesiapan dari RPH Cakung. Untuk TPnA/TPA Pulogadung, terdapat dua tempat, satu di Jagalan dan satu lagi di Pintu Air. Yang menarik dari lokasi TPnA/TPA di Pulogadung ini adalah bahwa Gubernur DKI Jakarta hanya menunjuk satu lokasi TPnA/TPA yaitu TPnA/TPA yang dikelola oleh BUMD dibawah naungan PT Dharma jaya yang beralamat di Jalan Jagalan. Sedangkan yang berlokasi di pintu air tidak mendapat rekomendasi dari Gubernur DKI karena lokasi merupakan milik swasta. 
Siti Mariam, Kepentingan Kebijakan Pembuatan Peraturan Daerah Provinsi Daerah Khusus...

1. TPA Pulogadung. Hasil pengamatan penulis terhadap kedua lokasi di Pulogadung, ternyata lokasi Pintu Air lebih layak sebagai tempat penampungan/pemotongan ungags dibanding dengan Jagalan. Letak strategisnya yang berdekatan dengan sungai dan tempat yang jauh lebih bersih dibandingkan Jagalan. Namun penulis tidak mendapatkan jawaban kenapa Pintu air tidak direkomendasikan oleh suku Dinas peternakan Jakarta Timur.

2. TPA Petukangan Utara. Hasil survey juga memperlihatkan bahwa TPnA/TPA Petukangan Utara di wilayah Jakarta Selatan tidak siap. Saat penulis melakukan survey, lokasi tengah diurug setinggi kurang lebih satu meter, karena lokasi rawan banjir, merupakan Kebun Penelitian dan Pembibitan Tanaman Pangan milik Dinas Pertanian

3. TPA Cakung. Pada saat penulis mengikuti rapat Tim Sukses Perda, yang berlangsung di Kantor Dinas Kelautan dan Pertanian, Jalan Gunung Sahari, diperoleh informasi bahwa Lahan di Rumah Potong Hewan (RPH) Cakung akan di segera di bangun. Namun pada saat itu belum dilakukan lelang tender untuk pembangunan serta penyediaan alat. RPH Cakung ini merupakan BUMD dibawah pengelolaan PT Dharmajaya.

4. TPA PT Kartika. Merupakan satusatunya pemotongan ayam (TPA) milik swasta yang ditunjuk pemerintah, berlokasi di Srengseng Jakarta Barat. Dengan kapasitas tampung 10.000 ekor, PT Kartika tidak dapat menampung jumlah ayam hidup yang masuk ke wilayah Jakarta barat. Penunjukan PT Kartika melalui Keputusan Gubernur Provinsi DKI Jakarta merupakan diskriminatif terhadap pelaku usaha unggas lainnya, karena hak ekslusif ini hanya diberikan pada satu pelaku usaha perunggasan.
5. TPA Kapuk. RPU Kapuk merupakan RPU yang direncanakan akan dibangun oleh Pemerintah Kota Administratif Jakarta Barat, Karena adanya keberatan dari pelaku perunggasan di Jakarta Barat dengan penunjukkan PT Kartika sebagai satu-satunya pemotongan swasta yang ditunjuk berdasarkan keputusan Gubernur DKI Nomor 1909 Tahun 2009. RPU Kapuk direncanakan untuk menampung para penampung dan pemotong unggas di Jakarta Barat. Memiliki luas keseluruhan 22 ha, dengan peruntukkan untuk RPU seluas 3.2 ha.

2. Rantai Pendistribusian Unggas Hidup, Karkas dan Olahannya.

Dalam hal ini pemerintah DKI mengeluarkan Perda No 4 tahun 2007. Pemda DKI beralasan bahwa dengan adanya Perda ini maka stabilitas harga komoditas unggas pangan dapat dijaga demi mewujudkan ketahan pangan nasional. Pemda DKI melupakan bahwa sebagian besar para peternak kecil, pemasok ayam, pemotong ayam dan pedagang pengecer ayam, belum siap menghadapi persaingan bebas dengan modal besar dari industri local maupun luar negeri dan unggas impor yang jauh lebih murah. Kebijakan ini menyebabkan kehidupan masyarakat perunggasan di DKI khususnya dan masyarakat perunggasan pada umumnya semakin terpuruk.

Apabila relokasi penampungan dan pemotongan ayam tetap dilakukan ke lima lokasi yang telah ditetapkan oleh gubernur DKI Jakarta, maka alur pendistribusian unggas akan terputus tanpa melalui penampung dan pemotong ayam. Karena pemda DKI Jakarta memberikan dua alternatif pemasukan ungags ke DKI yaitu dalam bentuk karkas langsung ke pasaran ataupun dalam bentuk unggas hidup ke lima lokasi yang ditetapkan Gubernur DKI Jakarta. Ke depannya semua unggas yang masuk ke DKI Jakarta hanya berupa ayam beku. Ini memberikan peluang penggunaan zat pengawet pada pruduksi unggas sehingga 
keamanan terhadap konsumen malah tidak ada.

Dari sudut pandang produsen, produksi unggas beku memang dapat mengurangi biaya kematian karena penyakit, dari sudut jaminan keamanan konsumen, hal ini merugikan konsumen karena tidak dapat terkontrol ayam sehat dan tidak sehat. Berkaitan dengan pendistribusian unggas, patut dicermati ciri umum dari negara berkembang adalah lemahnya kelembagaan pemasaran yang menyebabkan mata rantai pemasarann produk-produk pangan menjadi sangat panjang, karena harus melalui berbagai system kelembagaan informal. Berkaitan dengan kebijakan Perda No 4 tahun 2007, dampak sosial ekonomi terhadap pelaku pendistribusian unggas sangatlah besar. Mengingat di Provinsi DKI Jakarta saat ini terdapat 1.153 lokasi TPA.

Perda No 4 tahun 2007 mengatur tempat penampungan ayam (TPnA) dan tempat pemotongan ayam (TPA), yang akan ditetapkan oleh Gubernur, sedangkan yang sudah ada akan direlokasikan ketempat yang sudah ditetapkan Gubernur secara bertahap dalam jangka waktu 3 tahun. Konsekuensi pelaksanaan Perda akan dirasakan langsung oleh pelaku perunggasan yang menggantungkan hidupnya dari pekerjaan tersebut dari seperti pemilik penampungan ayam, tukang potong ayam, pedagang eceran ayam hidup dan peternak yang memasok ayam hidup untuk memenuhi kebutuhan ayam warga DKI Jakarta. Kebijakan relokasi dan masuknya ayam beku tidak dapat menjamin kehalalan produk unggas unggas yang telah dipotong, karena penggunaan mesin pemotong otomatis dan pemingsanan terlebih dahulu terhadap ayam yang dipotong. Tidak ada jaminan bila terdapat ayam yang dipingsankan langsung mati sebelum dipotong.

Dampak Kebijakan Perda Nomor 4 Tahun 2007 Terhadap Usaha Perunggasan

1. Dampak terhadap pelaku usaha perunggasan yang sudah ada baik di pasar maupun terhadap peternak unggas.
Apabila Perda No 4 Tahun 2007 diiberlakukan, maka Pemda DKI tidak mendukung pengembangan unggas lokal asli bangsa kita yaitu "Ayam Kampung". Ayam kampung yang merupakan plasma nuftah asli yang dimiliki bangsa Indonesia akan menjadi hewan langka yang hanya dapat ditemui di kebun binatang ataupun pusat-pusat penelitian. Pemeliharaan ayam kampung selama ini merupakan subsisten pertanian yang merupakan sektor peternakan. Merupakan sektor usaha kerakyatan, yang berbeda cita dan rasanya bila dibandingkan dengan ayam produksi industri. Jutaan keluarga ekonomi lemah yang bergantung pada ayam kampung akan kehilangan mata pencahariannya. Patut dipertimbangkan adat istiadat, budaya masyarakat dan ritual ibadah yang tetap masih menginginkan penggunaan ataupun mengkonsumsi ayam kampong hidup sebelum diolah untuk dikonsumsi.

Introduksi ayam ras di Indonesia terjadi pada awal 1970- an dengan dalih memenuhi kebutuhan gizi, membuka peluang usaha, menciptakan lapangan kerja, dan memanfaatkan sumber daya lokal. Proses introduksi yang dimulai di sektor produksi, kemudian meluas pada sektor investasi, distribusi dan konsumsi. Empat strategi yang ditempuh oleh negara maju adalah melalui exporting (ekspor langsung maupun tidak langsung), licencing (kontrak dan waralaba), joint venture (kerjasama usaha), dan direct investment (investasi langsung). Melalui empat strategi tersebut, perunggasan Indonesia tumbuh dan berkembang, namun tidak berakar pada sumber daya local yang dimiliki Indonesia.

Introduksi ayam ras dari hulu sampai hilir membawa dampak negatif bagi unggas lokal. Secara perlahan namun pasti, unggas lokal mengalami proses marginalisasi. Tidak ada kemajuan yang signifikan pada sektor produksi, distribusi, investasi, maupun konsumsi unggas lokal. Ungas lokal hanya dipelihara oleh orang-orang desa dengan cara tradisional sebagai usaha sampingan. Produk unggas lokal semakin mahal dan menjadi barang mewah di negeri sendiri. Ditunjuknya 
Siti Mariam, Kepentingan Kebijakan Pembuatan Peraturan Daerah Provinsi Daerah Khusus...

satu perusahaan swasta (PT Kartika) di Jakarta Barat, dalam pengelolaan pemotongan unggas yang masuk ke DKI maka Pemda DKI mendukung terciptanya usaha monopoli dalam bidang perunggasan (pelanggaraan UU No.5 Tahun 1999, tentang larangan prakek monopoli dan persaingan usaha tidak sehat).

Dengan mengacu pada pengaturan masalah-masalah kelangsungan peternakan dan kesehatan hewan yang sebagian besar masih berpijak pada kaidah internasional, pemda DKI belum memiliki dasar pijakan sendiri dalam mengelola pengendalian pemeliharaan dan peredaran unggas. Pemda DKI juga menolak bertanggung jawab terhadap seluruh kerugian ekonomi yang dihadapi pelaku perunggasan pada saat unggas terindikasi, terinfeksi virus flu burung. Adanya pasal ini jelas berpotensi menambah kerugian yang harus ditanggung penampung, pemotong, dan pedagang pengecer unggas di Jakarta.

Sanksi pidana kurungan paling lama 3 (tiga) bulan atau denda paling banyak Rp.50 juta rupiah menunjukan arogansi dari pemda DKI Jakarta yang ingin lepas dari tanggung jawab, pembinaan terhadap pelaku perunggasan di DKI Jakarta. Pasal - pasal tersebut diatas mangabaikan prinsip - prinsip ekonomi, perlindungan, rasa aman, dan keberlangsungan hidup rakyat Indonesia sebagaimana yang dimanatkan dalam Undang - Undang Dasar 1945, khususnya alinea keempat pembukaan, bab XA tentang Hak Asasi Manusia, Pasal 28A dan Bab XIV tentang Perekonomian Nasional dan Kesejahteraan Sosial, Pasal 33, ayat 4. Yang menyatakan "Perekonomian nasional diselenggarakan berdasar atas demokrasi ekonomi dengan prinsip kebersamaan, efisiensi berkeadilan, berkelanjutan, berwawasan lingkungan, kemandirian, serta dengan menjaga keseimbangan kemajuan dan kesatuan ekonomi nasional".

Dalam hal ini, kebijakan Perda No 4/2007 harus dimengerti dan dipahami oleh seluruh pelaku usaha perunggasan sampai sejauh mana dapat mematuhi Perda ini Sebagai ibukota Negara, DKI Jakarta selalu menjadi sorotan termasuk dalam pengendalian flu burung. Keberadaan Perda No 4 tahun 2007 ini mewajibkan adanya izin bagi siapa saja yang memelihara unggas pangan di wilaya DKI Jakarta. Untuk mendapatkan izin tersebut, disebutkan harus memenuhi beberapa persyaratan. Salah satunya lokasi kandang setidaknya berjarak $25 \mathrm{~m}$ dari pemukiman. Penulis juga melakukan survey ke pasar-pasar di wilayah DKI Jakarta, ada beberapa pasar yang telah direnovasi dimana disiapkan bangunan untuk pemotongan ayam di sudut belakang pasar. Salah satunya adalah pasar Kedoya. Di pasar Kedoya ini, pemotongan terpisah dengan komoditas unggas yang di pajang di display. Penjualan daging ayam seperti ini merupakan satu bentuk penyediaan ayam segar bagi konsumen. Bukan ayam beku yang diambil dari lemari pendingin/freezer. Rencana renovasi pasar Kedoya ini sebetulnya dilakukan sejak tahun 2007, Juli 2010 pembangunan telah mencapai $90 \%$.

Di Jakarta Barat sebelumnya telah ada pasar yang memisahkan pemotongan unggas dengan daging ayam yang di pajang yaitu Pasar Puri Indah. Pada saat Komisi Flu Burung bekerjasama dengan Departemen Pertanian, Departemen Kesehatan, FAO dan USAID menunjuk Pasar Bintaro di Tangerang sebagai proyek percontohan pasar sehat, DKI Jakarta sendiri telah memiliki pasar yang sehat. Walau keberadaaannya masih sangat kurang. Berdasarkan informasi yang diperoleh penulis, penunjukkan Tangerang sebagai proyek percontohan disebabkan adanya temuan korban pertama flu burung dan ditemukannya ayam import di salah satu swalayan dikota Tangerang tahun 2007.

Implementasi dan peningkatan keunggulan dalam ekonomi pengetahuan melibatkan tiga aktivitas dan lima komponen. Tiga aktivitas ekonomi pengetahuan yaitu: 1) knowledge production; aktivitas produksi didasarkan pengetahuan dan ide baru, 2) knowledge distribution; aktivitas penyebaran pengetahuan diantara anggota masyarakat, 3) knowledge consumption; penggunaan pengetahuan untuk menciptakan nilai dan membuat pengetahuan baru dari pengetahuan yang ada. Dalam upaya sosialisasi Dinas Kelautan dan Pertanian DKI Jakarta serta Suku Dinas Peternakan di lima wilayah DKI Jakarta pada Juni 2010 mengundang para penampung se DKI bertempat di Jl. Gunung 
Sahari dengan tujuan sosialisasi relokasi dan peningkatan pengetahuan teknologi pengolahan daging ayam. Berdasarkan informasi yang penulis terima, respon dari penampung tetap tidak menerima. Wilayah Jakarta Pusat hanya 3 (tiga) penampung yang hadir. Wilayah Jakarta Timur hanya lima yang menghadiri, untuk wilayah lainnya tidak ada yang datang.

\section{Dampak terhadap harga dan output}

Telur dan daging ayam merupakan sumber protein hewan yang mengandung berbagai zat gizi lengkap dengan harga yang murah. Sayangnya, pada saat ini permintaan konsumen terhadap komoditas unggas menurun dengan adanya pemberitahuan flu burung. Yang terbukti membuat ketakutan sejumlah anggota masyarakat terhadap produk unggas. Implikasi lebih luas, masalah flu burung juga berpengaruh menurunkan konsumsi protein hewani berbasis unggas. Menurunnya konsumsi protein akan berdampak pada kecerdasan. Pasalnya, protein hewani adalah pendongkrak kecerdasan yang cukup penting.

Peningkatan kesadaran masyarakat (public awarenss) serta promosi dan kampanye memang terus menerus dilakukan, namun masih bersifat sporadis, dilakukan oleh kelompok organisasi atau lembaga non pemerintah atau perusahaan tertentu. Hingga kini belum terlihat adanya gerakan kampanye gizi maupun hidup sehat dengan unggas sehat secara bersama-sama, berkelanjutan dan tersistematis. Perlu adanya grand design dan pelaksanaan yang berkesinambungan. Apabila di amati tabel 11 mengenai kegiatan penanggulangan avian influenza, ada niat baik Pemerintah Daerah DKI Jakarta untuk mengendalikan avian influenza. Namun prakteknya di lapangan, masalah pembebasan tanah masih merupakan kendala. Sehingga hingga akhir tahun 2008 Pemerintah DKI Jakarta, dalam hal ini tidak mampu mempersiapkan lahan yang diperuntukkan untuk penampungan dan pemotongan unggas di DKI Jakarta. Pembangunan Rawa Kepiting merupakan lokasi yg memang sejak awal telah ada, begitu pula dengan Pulogadung. Pemerintah DKI Jakarta memberikan kepada lima wilayah di DKI Jakarta untuk mempersiapkan sendiri lahan sebagai tempat penampungan dan pemotongan unggas.

Pada 3 Januari 2010 penulis mengahadiri undangan dari Tim Sukses Perda No 4 Tahun 2007 dalam acara work shop di Hotel Ibis. Work shop merupakan koordinasi dengan lintas sektoral dan lintas provinsi. Ke 5 (lima) Kepala Suku Dinas dari 5 (lima) wilayah di DKI hadir, dihadiri pula oleh dinas perdagangan, pihak keamanan dari kepolisian, dinas trantib dan DLLAJR. Selain itu hadir pula perwakilan dari FAO dan Dinas Peternakan dari wilayah terdekat DKI Jakarta yaitu dari Bogor, Tangerang dan Bekasi. Nampak keseriusan Dinas Kelautan dan Pertanian DKI Jakarta dalam mengimplementasikan Perda No 4 Tahun 2007.

Pada 23 Desember 2009, kembali penulis menghadiri rapat tim sukses Perda No 4 Tahun 2007, hadir pada saat rapat perwakilan dari PT Dharma jaya. Penulis mempertanyakan mengenai kesiapan lokasi TpnA/TPA, dan kesiapan tekhnis pada saat tanggal 24 April 2010 Perda akan diberlakukan. Karena berdasarkan hasil survei, DKI Jakarta belum siap untuk memberlakukan Perda No 4 Tahun 2007. Penulis juga menyampaikan dampak yang terjadi bila Perda diberlakukan. Jawaban dari Kepala Dinas Kelautan Dan Pertanian, Bpk Eddy Setiarso adalah "Tetap jalan atau jalan dengan catatan".

Wabah penyakit yang disebabkan virus AI sub tipe H5N1 ini pada awalnya hanya menyebabkan kematian pada jutaan unggas , baik ayam ras maupun lokal. Namun, pada periode 2005 hingga awal 2007 wabah AI telah merengut 60 - an nyawa manusia, dan menempatkan Indonesia sebagai negara dengan korban AI terbanyak di dunia. Jumlah korban AI sebenarnya jauh lebih sedikit dibandingkan korban kecelakaan lalu lintas, korban narkoba, korban HIV/AIDS, korban rokok, korban kapal Senopati Nusantara, korban pesawat Adam Air, korban pesawat 
Siti Mariam, Kepentingan Kebijakan Pembuatan Peraturan Daerah Provinsi Daerah Khusus...

Garuda, maupun korban penyakit DBD. Namun, gencarnya pemberitaan media informasi massa, utamanya televisi dan koran, tentang serangan flu burung pada manusia mengakibatkan kepanikan yang luar biasa di masyarakat. Dampak selanjutnya tidak saja pada penurunan konsumsi daging dan telur ayam yang mencapai $70 \%$ tetapi adanya keputusan depopulasi unggas lokal. Di Jakarta pemilik unggas lokal dipaksa atau terpaksa menyerahkan ternak unggas lokal miliknya untuk dibantai secara massal. Keputusan serupa dilaksanakan di beberapa daerah yang diuga menjadi pusat penyebaran virus flu burung. Meskipun pemerintah berjanji akan memberikan konpensasi, namun sampai sekarang tidak satu pun peternak yang menerima uang kompensasi yang dijanjikan pemerintah.

Dampak wabah flu burung ternyata tidak berhenti sampai pada pemusnahan unggas lokal. Dampak berikutnya adalah ketergantungan Indonesia pada vaksin flu burung import. Sejak 2005, Indonesia mengirim virus ke Laboratorium WHO karena laboratorium Indonesia dianggap belum memenuhi syarat. Sementara agen kesehatan negara lain berusaha mengambil specimen ke lokasi korban atau rumah sakit sakit di Indonesia. Ternyata virus flu burung strain Indonesia telah dikembangkan menjadi vaksin di Australia pada awal Pebuari 2007. Virus H5N1 yang diserahkan ke WHO untuk didentifikasi dan dilihat perubahan untuk kepentingan dunia, ternyata dimanfaatkan untuk pembuatan vaksin tanpa sepengetahuan negara pengirim. Negara pengirim virus harus membayar mahal untuk itu vaksin itu. Mekanisme ini membuat negara kaya semakin kaya, dan negara miskin makin miskin. Ditegaskan oleh Menteri Kesehatan Siti Fadilah Supari (Kompas 11 April 2007) sebuah bangsa yang merdeka tetapi masih bergantung pada bangsa lain, sebenarnya bangsa itu masih terjajah.

Perhatian masyarakat terhadap $\mathrm{Flu}$ Burung sementara mereda, seiring dengan fokus pemberitaan media massa yang beralih pada peristiwa kecelakaan kereta api, kapal laut, dan pesawat terbang, banjir di ibukota, lumpur sidoarjo, kekerasan IPDN, serta wabah DBD. Namun pada suatu saat wabah flu burung akan kembali berulang dan berulang dan keputusan yang sama, yaitu depopulasi unggas lokal. Perlahan namun pasti unggas lokal akan mengalami kepunahan, dan pada saat unggas lokal hanya kenangan. Disadari atau tidak flu burung merupakan sebuah bentuk Bioterorisme dan senjata Neo Kolonialisasi yang didalangi negara kaya dan tujuan menghancurkan unggas lokal dan menciptakan ketergantungan total dan permanen pada ayam ras mulai pengadaan sarana produksi, teknologi produksi, investasi, distribusi, sampai konsumsinya.

Terkait penyakit Flu Burung (AI), apabila penangulangannya terkoordinasi lebih baik maka selain kesinambungan produksi perunggasan dapat dijaga juga rasa aman masyarakat konsumen dapat segera dipulihkan untuk pada gilirannya mengalirahkan kembali pasar hasil unggas. Rendahnya daya beli masyarat yang berkolerasi dengan banyaknya jumlah orang miskin dan tingginya angka pengangguran pemecahannya akan menyangkut dengan kebijakan pembangunan nasional yang berorientasi kepada menyejahterakan kehidupan rakyat dalam berbagai aspeknya. Pemberdayaan pertanian harus menjadi fokus dalam pembangunan nasional, karena selain terkait dengan ketahanan dan kedaulatan pangan juga mempertimbangkan besarnya kontribusi sektor ini dalam peningkatan kesejahteraan masyarakat kedesaan, sehingga jumlah penduduk miskin yang jumlahnya cukup memprihatinkan dapat berkurang, Sektor perternakan selain sebagai penyedia pangan juga merupakan penyedia lapangan kerja yang efektif untuk meningkatkan kesejahteraan rakyat.

Pentingnya sektor pangan telah membuat negara maju berbalik arah memperkuat industry pertanian. Pada awalnya, diprediksikan Negara-negara industri maju akan menuju masyarakat ilmiah di masa sektor jasa dan teknologi informasi dan mendominasi kegiatan ekonomi. Sementara sektor industri dan pertanian akan dire-alokasi ke Negara berkembang. "Di luar dugaan, ternyata Negara maju masih tetap akan mempertahankan keunggulan kompetitif sektor pertanian, utama produk pangan. 
Alasan sektor pertanian sulit direkolasi dan masalah pangan sensitive terhadap kondisi social budaya, ekonomi, politik, dan keamanan dunia. Surplus pangan di America Serikat dan Kanada misalnya, ternyata tidak akan mampu menutup kekurangan produksi akibat kegagalan panen pangan di China dan di India. Kalau itu sampai terjadi, maka dunia khususnya Asia, termaksud Indonesia akan mengalami instabilitas kecenderungan memproduksi biofuel dari hasil tanaman pangan seperti jagung, tebu, sawit dan lainlain, " imbuhnya. Untuk itu Yasin mengajak semua pihak guna memanfaatkan dana dan lahan secara baik untuk megentaskan pengangguran di Indonesia.

13 Agustus 2007 melalui Keputusan Menteri Pertanian (Kepmentan) No. 61 tahun 2007 memutuskan membuka keran impor bubur ayam atau mechanically deboned meal (MDM). Kebijakan baru ini tidak hanya berlaku untuk impor daging asal unggas tapi juga dari ruminansia besar seperti sapi. Kalangan pengusaha ternak, mengibaratkan impor MDM in bisa bagaikan matabor memang ujungnya kecil, tapi dampaknya kan merusak industri perunggasan nasional. Masuk MDM bakal membuka peluang masuknya paha dan sayap ayam atau chicken leg quarter (clq) asal Amerika serikat ke Indonesia bila ini terjadi, kalangan perternakan bisa kian mengalami keterpurukan. Pihak pusat informasi pasar (Pinsar) unggas nasional mengungkapkan, para peternak sudah mengingatkan Menteri Pertanian terkait risiko memasukan MDM. Namun Menteri Pertanian terbukti tetap memaksakan kebijakan yang akan berdampak buruk bagi peternak unggas di desa-desa. Mengapa demikian? Karena peranan perunggasan sebetulnya amat penting atau seperti lokomotif perekonomian nasional dari desa ke kota. Masuknya MDM dan kalau benar disusul CLQ bias dipastikan memukul warga desa sejak petani jagung, padi, kedelai sampai peternakan yang pada gilirnya bakal merusak ekonomi pedesaan.

Model pendekatan pembangunan ekonomi yang demikian, di sektor pertanian dan peternakan dampaknya tercermin tidak saja dari kegagalan kita mewujudkan swamsembada sejumlah hasil-hasil pertanian strategis, tetapi juga kurang berkembangnya kegiatan usaha agribisnis yag berbasis peternakan, seperti usaha peternakan sapi potong, sapi perah, perunggasan dan usaha ternak lainnya. Terus membengkaknya angka impor daging dan susu, sering bergejolaknya bisnis perunggasan akibat fluktuasi harga sarana produksi, sepenuhnya menggambarkan buruknya kinerja pembangunan disektor ini. Ini masih bias ditambah dengan kebijakan penanggulangan penyakit hewan, yang pada tingkat implementasinya di lapangan masih jauh dari memenuhi harapan. Secara ekstrim hal ini terlihat pada tidak berjalannya kebijakan penanggulangan flu burung, untuk memposisikan Indonesia sebagai Negara flu burung terparah di dunia.

Wabah flu burung yang menimpa negara kita sangat meresahkan masyarakat, terutama para peternak unggas. Pasalnya unggas menjadi "terdakwa" sebagai salah satu pembawa dan penyebar virus H5N. Imbasnya, budidaya perunggasan menjadi sektor usaha yang paling terpukul akibat munculnya wabah flu burung. Parahnya, pada perkembangan wabah flu burung selanjutnya, unggas seakan sebagai hewan yang wajib dimusnahkan, karena diyakini sebagia sumber penularan. Indonesia adalah negara yang dianggap tidak mampu mengatasi masalah flu burung, karena wabah ini terus berlanjut. Selain itu, flu burung juga tidak hanya menjangkit unggas saja, namun sudah menimbulkan korban pada manusia. Penanganan flu burung yang berlarut-larut ini, membuat kegelisahan Siti Fadilla Supari, Menteri Kesehatan RI. Dalam tataran global, beliau merasa adanya ketidakadilan dalam penanganan virus flu burung. WHO sebagai lembaga kesehatan dunia, selama ini tidak memberikan informasi secara transparan tentang sampel flu bururng yang telah dikirimkan Indonesia.

\section{KESIMPULAN DAN SARAN}

Berdasarkan hasil pembahasan dapat diketahui kesimpulan sebagai berikut: 
Siti Mariam, Kepentingan Kebijakan Pembuatan Peraturan Daerah Provinsi Daerah Khusus...

1. Kepentingan kebijakan pembuatan Peraturan Daerah Provinsi DKI Jakarta Nomor 4 tahun 2007 adalah untuk mencegah perkembangan dan penularan penyakit flu burung sehingga masyarakat keseluruhan terbebas dari penyakit yang merisaukan serta memberikan kesempatan kepada pemda atau pihak swasta untuk mengelola tempat penampungan dan pemotongan ayam di lokasi baru.

2. Sebagai pelaksanaan Peraturan Daerah Nomor 4 Tahun 2007, Pemerintah Daerah DKI Jakarta menetapkan 5 (lima) tempat penampungan (TPnA) dan Tempat pemotongan (TPA) berdasarkan Keputusan Gubernur Nomor 1909 Tahun 2009 Tentang Perubahan Lokasi atas Keputusan Gubernur Nomor 1627/2009 tentang Lokasi Penampungan dan pemotongan ayam.

3. Perubahan sistem pendistribusian unggas dan ayam potong menyebabkan perubahan pola perdagangan ayam potong dan membuka peluang usaha baru yaitu industri pemotongan ayam (TPA) di wilayah penyangga yang berbatasan dengan provinsi DKI Jakarta.

Beberapa saran terhadap kepentingan kebijakan adalah sebagai berikut:

1. Hendaknya peran DPRD Provinsi DKI Jakarta lebih mengkaji rancangan Perda yang dibuat dengan tidak memberikan blanked norm (norma kosong). Dimana tidak sepenuhnya menyerahkan kepada Gubernur DKI Jakarta untuk mengisi dan menetapkan kriteria sendiri yang diinginkan pemerintah sehingga menguntungkan pelaku usaha unggas dengan modal yang besar bukan pelaku usaha perunggasan kecil dan menengah.

2. Kemajemukan kondisi sosial ekonomi pelaku usaha pendistribusian unggas di DKI Jakarta hendaknya menjadi acuan dalam pembentukan peraturan daerah dan seharusnya diakomodasi secara proporsional dan adil.

3. Pemerintah daerah provinsi DKI Jakarta hendaknya menyiapkan infrastruktur dan membina tempat penampungan ayam
(TPnA) maupun tempat pemotongan ayam (TPA) yang telah ada dengan mengkedepankan bio security dan keamanan produk unggas.

4. Pemerintah daerah Provinsi DKI Jakarta membuat SOP dan persyaratan NKV (Nomer Klatur Veteriner) bagi tempat pemotongan ayam (TPA) dari mulai skala usaha kecil, menengah maupun besar. NKV yang saat ini diberikan pada usaha perunggasan bermodal besar/industri perunggasan dan pelaku usaha perunggasan baru di tiap wilayah perbatasan provinsi DKI Jakarta merupakan kebijakan yang diskriminatif.

5. Membuat kebijakan terhadap usaha perunggasan ayam kampung yang merupakan plasma nuftah asli yang dimiliki oleh bangsa Indonesia. Sehingga anak cucu bangsa Indonesia masih bisa mengetahui ragam dan jenis ayam kampung/lokal yang semakin lama berkurang sejak adanya introduksi ayam ras di Indonesia dengan dalih memenuhi kebutuhan gizi, membuka peluang usaha, menciptakan lapangan kerja dan memanfaatkan sumber daya lokal.

6. Membangun, merenovasi dan melengkapi fasilitas di pasar tradisional dengan menyediakan ruang bagi pemasaran unggas hidup yang mengkedepankan bio security dan membuat tata tertib bagi semua pengguna pasar. Pada umumnya konsumen ayam kampung/lokal menginginkan ayam yang segar, dimana mereka dapat memilih langsung ayam hidupnya dan dipotong di tempat pemotongan di lokasi yang sama.

\section{DAFTAR PUSTAKA}

Anderson, James E. (1975). Public Policy Making, New York: Holt, Renealt and Winston.

Abidin, Said Zaenal. (2004). Kebijakan Publik. Jakarta. Yayasan Pancur Siwah.

A New Dictionary of Economics . 1966.

A New Dictionary of Economics and Commerce. 1974.

Basri, Faisal H. (2000). Reformasi dan Reorientasi Perekonomian Indonesia: Tinjauan Ekonomi Politik. Program 
Pascasarjana Universitas Indonesia Program Studi MPKP - FEUI. Jakarta.

Choudhury, Mausudul. Alam dan Malik, Uzir. Abdul, (1992). The Foundations of Islamic Political Economy. London. Macmillan.

CIDRAP (Center for Infectious Disease Research and Policy), (2004). Highly Pathogenic Avian Influenza (Fowl Plaque). Academic Health Center, University of Minnesota. Pp.14

CIVAS. (2008). Pedoman Penataan Pasar Unggas, Rantai Distribusi Unggas dan Produk Unggas. CIVAS bekerjasama dengan Komnas FBPI dan USDA.

Damayanti, R.NLP.I. Dharmayanti, R. Indriani, T. Syafriati, L. Parede, A. Wiyono dan Darminto. (2004). Deteksi Virus Avian influenza Subtive H5N1 pada Organ Ayam yang Terserang Flu Burung Sangat Patogenik (HPAI) pada Kasus Wabah di Jawa Timur dan Jawa Barat dengan Teknik ImonohistokimiaJITV (inpress).

Dye. Thomas R. (1978). Understanding Publik Policy Analysis an Introduction. Second Edition (terjemahan) Yogyakarta: Gadjah Mada Universitas Press.

Dunn William N. (1994). Public Policy Analysis: an Introduction Englewood Cliffs. New Jersey:Prentice hall.

Dunn William N. (2002) Public Policy Analysis An introduction. Second Edition (terjemahan). Yogya: Gadjah Mada Universcity Press.

Findi, MA. (2001). Analisis Transformasi Kebijakan Tata Niaga Pengadaan dan Penyaluran pada Industri Pupuk Indonesia. Jakarta: Tesis. Program Pascasarjana Program SPKP Universitas Indonesia.

Fadilah SS. (2009). Berkiblat Kata Hati Menggeser Tapal Batas Dunia. Kumpulan Wawancara. Pustaka Tokoh Bangsa.

Ikhsan, Mohamad. (2000). Kemelut Demokrasi di Era Reformasi. Jakarta: Institute For and Human Rights. The
Habibi Center vol.1 No.2 September November 2000.

Irawan, Prasetya. (1999). Logika dan Prosedur Penelitian: Pengantar Teori dan Panduan Praktis Penelitian Sosial bagi Masyarakat dan Penelitian Pemula. Jakarta: STIA-LAN Press.

Lane, J.E. dan Ersson, Suante. (1994). Ekonomi Politik Komparatif. Jakarta: Raja Grafindo Persada.

Mustopadidjaja, A.R.( 1992). Studi Kebijaksanaan, Perkembangan dan Penerapannya dalam Rangka Administrasi dan Manajemen Pembangunan. Jakarta: LP-FE UI.

Moleong, Lexy. J. (2002). Metodologi Penelitian Kualitatif. Bandung: Remaja Rosdakarya.

Nakamura, Smallwood Frank. The Politics of Policy Implementation. New York: St. Martins Press.

Ronohardjo, P. (1983). Penyakit Cengesan atau Selesma pada Itik Tegal, Bali dan Alabio. Penyakit Hewan XV (25). Semester I: 61-71.

Ronohardjo, P., S. Hardjosworo. S. Partoatmojo and M. Partadiredja. (1985). The Identification and Distribution of Influenza a Virus in Indonesia. Penyakit Hewan XVII (29), Semester I: 249 -257.

Ronohardjo, P.S. Partoutomo, S. Hastimo, N. Ginting and S. Poernomo. (1986). The Status of Duck Diseases in Indonesia. Penyakit Hewan XVIII (31). Semester I Tahun 1986: 86-93.

Salvatore, Dominick. (1996). Managerial Ekonomics in a Global Ekonomy. New York: Mc Graw-Hill,Inc.

Shahrir. (1994). Spektrum Ekonomi Politik Indonesia. Jakarta: Lembaga Penerbit Fakultas Ekonomi Universitas Indonesia.

Simanjuntak EP. (2007). Larangan Praktek Monopoli dan Persaingan Usaha Tidak Sehat. Berdasarkan UU No. 5 Tahun 1999. Bahan Ajar Mata Kuliah Hukum Anti Monopoli dan Persaingan Usaha Tidak Sehat. Magister Hukum Bisnis. Universitas Gajah Mada. Yogyakarta. 
Siti Mariam, Kepentingan Kebijakan Pembuatan Peraturan Daerah Provinsi Daerah Khusus...

Wiemer,David.L, Vining, dan Aidan R. (1992). Policy Analysis: Concept and Practice Englewood Cliffs. New Jersey, Prentice Hall.
W.J.S Poerwodarminta. (1985). Kamus Modern Bahasa Indonesia. Jakarta. 